\title{
Tourist Souvenirs of Eco-packaging Structure Optimization Design in Perspective of Lijiang River Culture
}

\author{
Liu Zhihong \\ Guangxi Normal University, \\ Guilin, Guangxi, China \\ 261607194@qq.com
}

\author{
ZHANG Yu-ting \\ Guilin College of Aerospace Technology, \\ Guilin ,Guangxi, China \\ 920070961@qq.com
}

\begin{abstract}
Article to the opportunity of development of Guilin tourist attractions souvenir packaging, with its profound cultural connotation and artistic taste as the basic point of Lijiang River, from unique structural optimization design of Visual angle to research, make souvenir package design visual branding and design concept. Illustrates a culture of Lijiang River tourist souvenir package design should reflect its simple Visual effects, a unique cultural connotation, and "beauty" packaging designed to embody the principle of eco-packaging concept. Confirm optimized souvenir wrapped in a substantial increase in sales, structure optimization design for ecological packaging provides a reliable method.
\end{abstract}

Keywords-Li River Culture, Tourist souvenirs, Ecological packing, Optimization design

\section{Introduction}

Tour souvenir package design should look at the Lijiang River of mining and its unique culture, symbol of refined culture, research and development in line with market products. Ecological packaging has become important research topics of the packaging industry. Guilin tourism development, prosperity brought to life for the souvenir market. At the same time, a lot of packaging and sale of souvenirs with local characteristics and discussion on hot topics of concern to the many businesses. As a historical and cultural tourist city of Guilin, the prosperity of its booming tourism souvenir opportunities. Diversification of tourist souvenirs, regional characteristics of Visual beauty needs to have cultural connotations and characteristics of packaging. From the perspective of environmental protection, to rethink the function of packaging and design, look for eco-packaging to meet the production, improving product competitiveness and reduce negative impacts on the environment. Article by collecting eco-packaging information, understanding the existing packaging development, in all its aspects, summarized the various measures against the eco-packaging. And through the investigation of eco-packaging, method of analysis and comparison of souvenir taken by the eco-packaging, and try to make a new design method of structural optimization of eco-packaging.

\section{Status quo of tour souvenir packing}

Guilin has a deep historical and cultural heritage and a large number of monuments and its unique geographical advantage, reserve provides many of the advantages of the

Project Source: Department of Guangxi Philosophy and Social Sciences "12th Five-Year Plan 2011 Youth Foundation of Guilin local folk culture of animation designed to promote research on the development of tourism economy" One of the outcomes (item number: 11FJY036) development of Guilin tourism resources. However, on souvenir package design is not caused by businessmen and the operator's attention, research shows that tour souvenir pack has the following main areas of problems.

\section{A Souvenirs packaging attention is not enough}

When Guilin's tourism revenues increased construction of tourism infrastructure environment continues to improve, and complementary tourism souvenir package of chulengmen situation in the market. Yangshuo West Street by human concern it, anywhere you can buy $\$ 1$ a souvenir, not to mention how technology, from the packaging, has discouraged many tourists, this a common phenomenon in and around Guilin tourism market. Art appearance, after all, is prerequisite to the visitors left a deep impression.

\section{B Innovation in packaging design concept is not new, weaker}

Guilin rural quaint, unique folk. In addition to tourist souvenir complex of imitation, imitation Cheung Pei Shan, simulating the camel Hill, mountains of the moon-like outside, fake impression of Guilin, with porcelain clay sculpture, paper-cutting, Lijiang painting Northern Guangxi, Guilin topic folk arts such as Ming Yu Chinese and foreign, became an important part of the cultural tourism resources of Guilin. However, many tourist souvenir production and packaging still remain in the traditional family model, this model led to the packaging manual fabrication and design materials, lagging behind. As clay sculpture in Guilin topic in most of the tourist market distribution, retail packaging waste plastic bags and old newspapers are basically used packages to withdraw, which gives buyers carrying inconvenient. Packaging of humble, tourist souvenirs itself had a strong distrust of the value.

Souvenir package design-conscious weak, mainly: packaging protection features, such as moisture, vibration, pressure and other poor, most of the tourist souvenirs packaging paper and plastic materials, nature materials characteristics determine the loss of some tourist souvenirs protection. Packaging structure is reasonable, rough art process, packaging design form a single, lack the necessary arts of decoration. Cultural connotation of Guilin is not enough, content, theme, pattern, choose older, formulated in the form of expression, cannot reflect the characteristics and personalities of the times of tourist souvenirs. Weak brand awareness, integration and serialization package need to be 
improved. Environmental awareness is not strong, after the selected material waste is very easy to cause environmental pollution.

\section{The unique design skills of tourist souvenirs eco-packaging}

Tour souvenir package design should reflect its simple Visual effects, a unique cultural connotation and perfect the structure optimization design of Lijiang River.

\section{A Simple visual effects}

Souvenir package design, embodiment in tourist souvenir characteristics at the same time, should also play a role in advertising, this calls for tourist souvenirs packaging design can show both unique visual charm, but also reflect the commercial value, chic design, better able to cater to the tourist souvenir collectors in general psychology. Tour souvenir packaging material of choice when in natural materials, suiting measures to local conditions, to simply the principle of moderate, such as wire can be selected, such as linen, cotton, rope; in processed form, as far as possible keep the natural texture of materials, easy processing, elaborately decorated. Design and craft link, should pay attention to the characteristics of the material itself and the reasonable combination of patterns, this combination need expressed using the Visual language of art. When people from consumer demand attention when a transformation of substances to the emphasis on spiritual direction, packaging design-national based strategic thought growing prominence [1]. Design by using elements of national culture should be kept in mind while seeking agreement on the concept, and not just a simple imitation. Cultural performance, not simply Visual elements such as characters, patterns, paper-cut simply depicted on the packaging, through the forms should be based on grasping the cultural connotations, its contents into cultivation, natural expression in the works.

\section{B Unique cultural connotation of Lijiang River}

Anthropologist Bronislaw Kasper Malinowski says: "in human social life, all the biological needs has been transformed into a cultural need" [2]. Tourist souvenirs of eco-packaging is unique to local culture forms, of strengthening the culture of design, to enrich the Visual language of expression and manifestation of national sentiment. Unique geographical features and special cultural environment, making a sweet mellow and normal tourism souvenir market and has a strong local characteristics. In the packaging and decoration, embodiment of the national culture is often triggers consumers moved inside the most fundamental factor [3]. Therefore, unique cultural connotation of Lijiang River of Guilin tourism souvenir market further prosperity of the first condition. Is the rapid development of tourism of Guilin province, visitors often want to see the local folk customs, tourist souvenirs as a carrier of culture, it has unmatched by other products of cultural connotations, such as Yangshuo impression Liu sanjie, Northern Guangxi folk paper-cutting, yuzi paradise clay sculptures, Lijiang painting-ink landscape painting. Especially foreign tourists, their way of life, tradition, and Chinese people quite different, more often with "traditional Chinese" souvenir of the easier to attract them, from here, the tourism souvenir package design should enhance national and regional culture, that call warrants our consideration [4]. Souvenirs: packaging design, should be reflected in local folk culture, pay attention to the specific natural and human environments to convey, from another perspective, knowledge and wisdom, reflect workers ', carries a profound process of design thinking.

\section{Perfect structure optimization design}

Wide variety of Guilin's tourism souvenir, successful packaging design should make the organic combination of packaging structure and appearance of tourist souvenirs, while reflecting souvenir characteristic, follow the "beauty" design principles. "By type" through market research, tourism souvenir market positioning, including tourist souvenirs appearance object, property, quality, sales, and consumption areas; " United States "means the decision styles and design ideas. "By making the United States the" packaging principles, should be based on grade design of tourist souvenirs, applying appropriate, scientific structure, Nice, economical and practical. "By making the United States the" packaging to better reflect the principle of eco-friendly packaging concept, at the same time, prevent price surge, caused by the excessive packaging material waste [5]. On the package structure, based on different characteristics and requirements of tourist souvenirs, emphasis on dimensions, material used, with a different structure for tourism souvenir packaging. "By making the United States the" principles of eco-packaging requirements of tourist souvenirs packaging structures pay attention to the following aspects: easy to use, portable and convenient, and retention of material nature, process is very simple, decorated, and reduce the amount of packaging materials used, concentrated packaging volume, give full play to its function of protecting tourism souvenir; improving the materials recycling rates. Packaging structures form, should fully take into account the diversity of the series features, packaging series design is a business on their own with a product packaging design form of unity and change. To form a unified vision of culture, to better highlight the brand's image. Packaging design from monomers to serialization, to play an advocacy role, strengthening consumer impressions, expanded brand influence [6]. Tourist souvenir series design, you can effectively enhance the market competitiveness of tourist souvenirs, nationalization of the series package can also promote tourism souvenirs in the international market share. Save costs at the same time, to a large extent structure optimization design of eco-friendly packaging concept.

\section{Developing tourism souvenirs theme taste of eco-packaging design}

Speaking from a psychological perspective, people are looking forward to the break, change hard and fast living, hope there are always new surprises there, enjoying the colorful life. Facing the demands of consumers, designers pay attention to the emotional needs of the people, tourist souvenirs outside the General packaging, research and development to expand to meet the needs of specific human emotion theme and taste package [7]. For souvenirs, and only if the purchaser to be brought home, to reflect its practical value, as a tourist souvenir treasures, gifts, friends and family, or as a room decoration. Almost all tourist souvenirs include some sort of "moral of Memorial, lucky, etc", packaging design is the sustenance of this moral characteristics, and this 
implication into souvenirs of added value. On the basis of its added value is in the packaging function.

\section{A Interesting design of tourist souvenir packing}

When architects designed the souvenir package design, collateral design stress and creative advertising mailings, among them, in addition to brand information, you should also appreciate the knowledge and culture of consumption of tourist souvenir. When buyers looking at and touching packaging, smell of body odour to the the invisible; when browsing through brochures, taste with the combination of Visual, Visual understanding to the cultural characteristics of the product, this intuitive experience to make it a better understanding of the tourist souvenirs of love, adds share exchange, appreciation and taste taste.

\section{B Theme design of tourist souvenir packing}

Tourist souvenirs and home life has a direct relationship, designed for tourist category of plots and holiday theme package makes it create a different atmosphere in a specific environment, will inject more affection and blessings for tourist souvenirs. Can also be held in Guilin for relevant international conferences, celebrations, events, activities and other organizers require to design the theme of ecological tourism souvenir packaging.

\section{Result and analysis}

The development of its tourism industry, cannot be separated from the research and development of tourist souvenirs. Research and development of tourist souvenirs, you can further contribute to the development of its tourism industry. As the development of tourism industry in Guilin province, there are inherit and carry forward the traditional culture of the advantages, it has a brilliant history, profound traditional culture, therefore, fine workmanship, unique, informative, and color harmony of packaging design is not only conducive to the transport and sale of souvenirs, also contribute to the enhancement of tourist souvenirs and art taste, conducive to the creation and promotion of the brand image. Souvenir package design should have a sense of national, but also have the modern sense, for it to truly achieve "protected goods, landscaping products, promotional merchandise," purpose [5].

\section{Conclusions}

Ecological design idea on the cultural perspective of Lijiang River ecological packaging analysis and structure optimization of tourist souvenirs, improved tourism souvenirs in extrusion deformation of box, increase the buffering properties of the packaging and sales results. Tourist souvenirs to withstand impacts of wider frequency, break the traditional souvenirs packaging forms. By optimizing the effect of force curve before and after comparison of confirmed sales significantly increased after the optimization of eco-packaging, consumers greatly improve, provided a feasible method for improvement of packaging design. Current packaging design of Guilin tourist products even though there are many shortcomings, but as long as the change in packaging design ideas, mining regional traditional cultural elements in Guilin, brand strategy in the implementation of the Lijiang River culture, into the ecological awareness, was able to achieve organic fusion of use value and aesthetic value of tourist souvenirs, promotion of Guilin in Guangxi and the rapid development of the tourism industry.

\section{Acknowledgments}

This choice of topics, is in reference to the original regional culture under the background of the Foundation in Guilin, in Guangxi Normal University for the design characteristics of the educational work of art, through practical design of case, after investigation and research project programme. Because of my professional knowledge level of superficial, many articles will exist where inadequate and subject to criticism, experts wanna please you. Here, I would like to thank all of my thesis 2012 international packaging Conference on Science and technology (ICPTS2012) experts from the Organizing Committee of the judges and staff. Their spirit of rigorous research, hard diligent work attitude, warm and full of style, I benefited from. At the same time, I would also like to thank my research paper help of Guilin travel to Wuhan University Professor shuailigong and Professor Yang Zheng and other academic colleagues, and paper reference or reference information in the compilation and documentation writers. Finally, I to to the most sincere feelings of appreciation over the years have all helped my friends! thank you.

\section{References}

[1] Huang Ying, Li Fei. nationalization in packaging design application [j]. printing world, 2005 (10): 12-13.

[2] Bronislaw Kasper Malinowski. culture [m.] Fei Xiao-Tong's translation. Beijing: Huaxia Publishing House, 2002.

[3] Pan Xiaowei. alcoholic product packaging design [j]. packaging engineering, 2008,29 (1): 114-145.

[4] Lv Feng, Lian Yi. thinking based on souvenir package [j]. packaging engineering, 2005,26 (5): 152-154.

[5] Liu Danlong. Shaanxi tourist arts and crafts packaging research on the design of Visual styles [j]. packaging engineering, 2010,7 (14): 63-65.

[6] Gao Li, Liu Zijian. application of color in series package [j]. packaging engineering, 2008,29 (3): 125-127.

[7] Rong Hu. warm taste culture-China wine package design [j]. packaging world, 2010,7 (4): 110-111.

[8] the East China Normal University Master degree thesis. current research on green packaging [EB]. cnki, August 2009.

[9] Liu Zhihong. harmonious · tradition and culture-study on the tendency of Chinese traditional architecture culture [j]. the literary world, December 2009.

[10] Ma Chundong. ecological design [m]. Beijing: higher education press, August 2007.

[11] Yu Lan. contents of feelings and analysis on the design of road-travel packages [j]. Decoration, 2008 (3): 134-135.

[12] LiuZhiHong. Researching of Culture about Guangxi Beibu Gulf low carbon living and eco-green urban[C]. Science Press USA Inc. 2011.10. 